\title{
A RESEARCH ON THE FACTORS INFLUENCING WHY CHILDREN ARE EFFECTIVE IN SENDING THE PARENTS TO THE VOLLEYBALL SCHOOL
}

\author{
Fatma Beyza Bilgiçi, \\ Murat Bilgiç², \\ Hüseyin Öztürk ${ }^{3}$ \\ İ̇önü University, \\ Faculty of Sport Science, \\ Turkey \\ 2Batman University, \\ High School of Physical Education and Sports, \\ Turkey \\ ${ }^{3}$ Gaziantep University, \\ Faculty of Sport Science, \\ Turkey
}

\begin{abstract}
:
This study has been prepared to search the determinant reasons why families are sending their children to volleyball schools. Research sample consists of families who are sending their children to Gaziantep Youth Services and Sports Provincial Directorate. A total of 204 people, comprising of 106 women and 98 men, participated in the study. We have been benefited from the expectation scale which was reformed by Meral (2010) to determine the reasons why parents are sending their children to football schools. The data obtained in this study statistically analyzed by using SPSS 22,0 package software. Descriptive statistical methods like frequency, percentage, average and standard deviation have been used in data evaluation in addition to student $t$-test which has been used for two independent groups, ANOVA and Tukey multiple comparison tests which have been used for comparing more than two independent groups. The results have been evaluated at $95 \%$ confidence interval and at a significance level of $p<0,05$. As a result of the study: parents with their children school volleyball the sender is mostly a housewife, trades/private sector, first-middle-school and high-school graduates, gender, marital status and number of children in the family sporting activities of children according to the major reasons for directing that there is no significant difference between were found as a result of research.
\end{abstract}

Keywords: family, volleyball, sport, child

' Correspondence: email murat.bilgic@batman.edu.tr 


\section{Introduction}

The main educational tool of raising and developing a healthy generation is sports. The place of sports is very important for people to continue their lives as healthy individuals and for their mental and physical development. Sports play an important role in helping people maintain their relationships in their own society and in other societies in the form of friendship (Meral, 2010). It is one of the elements that bring people closer to each other without discriminating between different languages, races and nationalities (Sezen, 1990). Also, sports, play, entertainment, health, profession and science (Voigt, 1998). Today, sport has entered the process of globalization and professionalization by going beyond the amateur spirit and the phenomenon of winning and losing as it was during the emergence process. As a result, the rules of the game, the expectations of the fans, the club organizations and the popularity of the branch and the athlete must be at the highest level (Soysal at.al, 2017). The most influential environment on a person from childhood to adolescence is the family. Families are the first unit that enables children to see the social and sports world (Keskin, 2006; Şimşek, 2005). The family who thinks that it will benefit the child's free time, physical and psycho-social development; They direct their children to a sports branch of their choice or to a branch that the child wants, thinking that it will provide a better future (Kılıçgil, 1998; Hutchinson, 2003).

The main purpose of sports branches is to increase the performance of the person or people who do sports and to ensure that the physical characteristics required by that sport develop in a continuous harmony (Şahin and Özdal, 2020). Volleyball, one of the most popular sports branches of today, is played by many people for professional and entertainment purposes. Individuals can play volleyball officially or as a hobby. For this purpose, in our study the factors affecting the families' reasons for sending their children to volleyball schools were investigated.

\section{Material and Methods}

In this section, the research model, population, sample, data collection method and statistical methods and techniques used in data analysis and interpretation are explained.

\subsection{Research Model}

The general screening model was used in our research, which aims to determine the reasons that are effective in the reasons why families send their children to volleyball schools (Özmen, 2000).

\subsection{Sample of the Study}

The population of the research consists of families who send their children to volleyball schools in Gaziantep. The sample group consisted of 204 (106 female, 98 male) parents. 


\subsection{Collection of Data}

In obtaining the research data, the personal information form and the expectation scale in the study on the Opinions of Families in Orienting Children to Sports, developed by Meral (2010), were used by taking expert opinion. In the first part, the personal information form consisting of 7 questions prepared by the researchers in accordance with the purpose of the research was used, and in the second part, the expectation scale was used to determine the Opinions of the Families in Orienting the Children to Sports. Cronbach's Alpha value was calculated for the reliability analysis of the question statements about the scale. The main purpose of the reliability analysis is; the aim is to determine whether all questions are perceived at the same level by the participants. Security analysis emerges by measuring the relationship between the statements that make up the measurement tool, whether they are consistent with each other or not. The reliability coefficient takes values between 0 and 1 , and as these values get closer to 1 , the reliability increases (Ural and Kılıç, 2005). Accordingly, the Cronbach's Alpha value was calculated as 0.786 . Therefore, the scale was found to be reliable.

\subsection{Statistical Analyzes}

While evaluating the findings obtained in the study, SPSS (Statistical Package for Social Sciences) for Windows 22.0 program was used for statistical analysis. While evaluating the study data, in addition to descriptive statistical methods (Percentage and Frequency), in the comparison of quantitative data, independent samples t-test was used for comparisons between groups of parameters with normal distribution in the case of two groups. In the case of more than two groups in the comparison of quantitative data, Oneway Anova test was used in the comparison of parameters between groups and Tukey test was used to determine the group that caused the difference, and the results were evaluated at the $95 \%$ confidence interval and the significance level of $\mathrm{p}<0.05$. Tables were created by taking into account the relationship levels of the data obtained through statistical programs with some variables, and the results of the research were obtained as a result of these tables.

\section{Results}

Table 1 shows the findings related to the personal characteristics of the participants. Participants were $52 \%$ (106 people) female and $48 \%$ (98 people) men, considering their age, maximum $44.1 \%$ (90 people) were between the ages of $31-40$, at least $15.7 \%$ (32 people) $26-3040.2 \%$ (82 people) of people between the ages of 41 and 41 years old, $40.7 \%$ (83 people) primary school, 20.1\% (41 people) middle school, $22.5 \%$ (46 people) high school and $16.7 \%$ (34 people) have a university and older, when their occupational status is evaluated, $18.6 \%$ (38 people) are officials, $16.2 \%$ (33 people) are employee, $29.9 \%$ (61 people) are tradesmen/private sector, it is seen that $35.3 \%$ (72 people) are housewives. 
Table 1: Personal Information Table of the Participants of the Research

\begin{tabular}{|c|c|c|c|}
\hline \multicolumn{2}{|l|}{ Personal Information } & $\mathbf{N}$ & $\%$ \\
\hline \multirow[t]{2}{*}{ Gender } & Female & 106 & 52,0 \\
\hline & Male & 98 & 48,0 \\
\hline \multirow[t]{3}{*}{ Age } & $26-30$ & 32 & 15,7 \\
\hline & $31-40$ & 90 & 44,1 \\
\hline & 41 years and older & 82 & 40,2 \\
\hline \multirow[t]{2}{*}{ Marital status } & Married & 184 & 90,2 \\
\hline & Single & 20 & 9,8 \\
\hline \multirow[t]{4}{*}{ Educational status } & Primary school & 83 & 40,7 \\
\hline & Middle school & 41 & 20,1 \\
\hline & High school & 46 & 22,5 \\
\hline & University and older & 34 & 16,7 \\
\hline \multirow[t]{4}{*}{ Occupational status } & Official & 38 & 18,6 \\
\hline & Employee & 33 & 16,2 \\
\hline & Tradesman/private sector & 61 & 29,9 \\
\hline & Housewife & 72 & 35,3 \\
\hline
\end{tabular}

Table 2: Number of Children in the Participant's Family

\begin{tabular}{|l|c|c|}
\hline & $\mathbf{N}$ & $\%$ \\
\hline $1-2$ & $\mathbf{7 9}$ & 38,7 \\
\hline $3-4$ & $\mathbf{6 6}$ & 32,4 \\
\hline 5 and older & 59 & $\mathbf{2 8 , 9}$ \\
\hline Total & $\mathbf{2 0 4}$ & $\mathbf{1 0 0}$ \\
\hline
\end{tabular}

Table 2 shows the number of children in the family of the participants was evaluated. According to this; It was determined that 38.7\% (79 people) had $1-2$ children, $32.4 \%$ (66 people) had 3-4 children, and $28.9 \%$ (59 people) had 5 or more children.

Table 3: Participants' Sports History

\begin{tabular}{|l|c|c|}
\hline & $\mathbf{N}$ & \% \\
\hline Yes & 112 & 54,9 \\
\hline No & 92 & 45,1 \\
\hline Total & $\mathbf{2 0 4}$ & $\mathbf{1 0 0}$ \\
\hline
\end{tabular}

The sports backgrounds of the participants were evaluated in Table 3. It was determined that $54.9 \%$ of the participants (112 people) had done sports before, and $45.1 \%$ (92 people) did not do sports.

Table 4: The Comparison of the Main Reasons for the Participants' Directing Children to Sports Activities and the Variable of Sports History

\begin{tabular}{|l|l|c|c|c|c|c|c|}
\hline & Groups & N & Mean & Std.Dev \pm & $\mathbf{f}$ & $\mathbf{p}$ & Significant difference \\
\hline \multirow{2}{*}{ Gender } & A-Yes & 112 & 2,01 & 0,06 & \multirow{2}{*}{1,48} & $<0.05$ & \multirow{2}{*}{ A-B } \\
\cline { 2 - 6 } & B-No & 92 & 2,09 & 0,06 & & & \\
\hline
\end{tabular}


When Table 4 is examined, a statistically significant difference was found between the previous sports history of the parents participating in the study and their sending their children to volleyball $(<0.05)$. According to this, it is seen that the reasons for sending their children to volleyball are higher for those who have a previous sports background than those who do not have a sports background $(<0.05)$.

Table 5: A Comparison of the Main Reasons of the Participants for Directing Children to Sports Activities and the Variable of Educational Status

\begin{tabular}{|l|l|l|c|c|c|c|c|}
\hline & Groups & N & Mean & Std.Dev \pm & $\mathbf{f}$ & $\mathbf{p}$ & $\begin{array}{c}\text { Difference } \\
\text { between groups }\end{array}$ \\
\hline \multirow{4}{*}{$\begin{array}{l}\text { Educational } \\
\text { status }\end{array}$} & A. Primary school & 83 & 1,85 & 0,06 & & & \\
\cline { 2 - 5 } & B. Middle school & 41 & 2,09 & 0,06 & \multirow{3}{*}{6,47} & $<0.05$ & A-C \\
\cline { 2 - 5 } & C. High school & 46 & 2,35 & 0,06 & & & \\
\cline { 2 - 5 } & D. University and older & 34 & 2,04 & 0,06 & & & \\
\hline
\end{tabular}

When Table 5 is examined, there is a significant difference between the education levels of the parents participating in the research and the reasons for sending their children to volleyball school $(\mathrm{p}<0.05)$. According to Table 5, it was seen that those who participated in the research with primary school education got significantly higher scores than high school graduates in terms of sending their children to sports.

Table 6: A Comparison of the Main Reasons of the Participants for Directing Children to Sports Activities and the Variable of the Number of Children in the Family

\begin{tabular}{|c|c|c|c|c|c|c|}
\hline Groups & $\mathbf{N}$ & Mean & Std.Dev \pm & f & $\mathrm{p}$ & $\begin{array}{c}\text { Difference } \\
\text { between groups }\end{array}$ \\
\hline A. $1-2$ & 79 & 2,25 & 0,06 & \multirow{3}{*}{1,271} & \multirow{3}{*}{$<0.05$} & \multirow{3}{*}{$\begin{array}{l}A-B \\
A-C\end{array}$} \\
\hline B. $3-4$ & 66 & 1,88 & 0,06 & & & \\
\hline C. 5 and older & 59 & 1,95 & 0,05 & & & \\
\hline
\end{tabular}

When Table 6 is examined, it is seen that there is a significant difference between the reasons for sending the parents to the volleyball school according to the number of children participating in the research $(\mathrm{p}<0.05)$. It was observed that those with $1-2$ children got significantly higher scores in terms of sending their children to sports than those with 3-4 or 5 or more children.

\section{Discussion}

There is no statistically significant difference between sending their children to volleyball schools according to the gender of the parents participating in the research $(\mathrm{p}<0.05)$. Looking at different studies, it is seen that there are similar results. In the research named the reasons for these choices of primary school students who choose to be volleyball players and the effect of school, family and society factors; it was found that children's doing sports was approached positively and there was no significant difference between 
gender (Esen, 2010). In a different study, no statistically significant difference was found between the gender groups of the parents (Keskin, 2006).

A significant difference was found between the sports history of the parents participating in the study and their sending their children to volleyball $(<0.05)$. According to this result, it is seen that the reasons for sending their children to volleyball are higher for those with a previous sports background than those without a sports background $(<0.05)$. Looking at the literature, there are studies with similar results. According to a research result, the status of parents doing sports has a positive effect on directing their children to sports (Öncü, 2007). In a different study, has been revealed that the presence of sportsmen in the family has an effect on the child's doing sports (Kotan, 2007).

When the education level of the parents participating in the research and the reasons for sending their children to volleyball school were examined, it was seen that those who had primary school education got a significantly higher score than high school graduates in terms of sending their children to sports $(<0.05)$. When we look at the literature, studies with similar results can be seen. In a study conducted on 398 Nepalese children aged 11-14 years, it was found that children's orientation towards sports was related to the education level of their families (Watkins \& Regmi, 1989). In the research conducted by Demir on 481 children aged 7-14 who came to Istanbul Burhan Felek Sports Facility Summer Sports School, the most important factor in directing children to sports was family; determined that it increases in parallel with the education level of the parents (Demir, 1996). In a different study, it was determined that the education level of the parents is effective in the child's sportive activity (Kayıkçı, 2007; Kotan, 2007).

\section{Conclusion}

Considering that the parents participating in the research are mostly between the ages of $31-40$, it is seen that they are young parents, the majority of them are primary school graduates, that is, they have a low level of education, and when their profession is considered, it is seen that they are mostly housewives or in the trades / private sector. According to the gender of the parents participating in the research, there is a statistically significant difference between sending their children to volleyball schools, and it is seen that the reasons for sending their children are higher. A significant difference was found according to whether the parents participating in the study did sports before or not. According to this result, it is seen that people who do sports before send their children to sports at a higher level than people who have not done sports. It was seen that the parents who participated in the study had a significantly higher score for sending their children to sports than those who graduated from primary school. The reasons for sending the parents participating in the study to the volleyball school of the families with primary school education were found to be statistically higher than the high school education level.

As a result, it was determined that the most important reasons for the participants to send their children to volleyball schools were to improve their sensory, cognitive and 
physical characteristics, to use their free time, to facilitate their participation in group activities, to reveal their talents and to facilitate their personality development. Looking at the results obtained, we can say that sports have a great place in the physical, spiritual and mental development of children, and as long as these results are acted upon, it will make positive contributions to the lives of young people.

\section{Conflict of Interest Statement}

There are no potential conflicts of interest on this article.

\section{About the Authors}

Mrs. Fatma Beyza Bilgiç has PhD of Science degree of sport science field.

Dr. Murat Bilgiç Batman, University High School of Physical Education and Sports, Turkey.

Dr. Hüseyin Öztürk is Associate Professor Doctor at Gaziantep University, Turkey.

\section{References}

Demir A, 1996. Factors affecting the orientation of children aged 7-14 to sports. PhD Thesis, University of Gazi Marmara.

Esen SA, 2010. The causes behind the choices of students in primary schools choose to be volleyball players and the effects of school, family and social factors. Master's Thesis, University of Marmara.

Hutchinson SL, Baldwin CK, Caldwell LL, 2003. Differentiating Parent Practices Related Adolescent Behavior in the Free Time Context, Journal of Leisure Studies, 35(4), 396-422.

Kayıkçı N, 2006. The determination of the family support and pressure for the leisure time sportive activities of the primary school students aged between 7-12 (The sample for the province Ankara). Master's Thesis, University of Gazi.

Keskin V, 2006. Expectations of parents leading their children to sport beklentileri. Master's Thesis, University of Afyon Kocatepe.

Kilcigil E, 1998. Social environment-sport relations. Bagirgan Publishing House, Ankara.

Kotan Ç, 2007. The influence of school and family on sportsman students in elementary education in their doing sport. Master's Thesis, University of Sakarya.

Meral S, 2005. A research on the factors influencing parents for sending their children to football schools. Master's Thesis, University of Marmara.

Öncü E, 2007. Expectations and attitudes of parents towards participation of their children into physical education classes. PhD Thesis, University of Gazi.

Özmen A, 2000. Sampling methods in applied research, Anadolu University Press, Eskişehir.

Sezen Y, 1990. Basic information and discussions in sociology and sociology of religion, M.Ü.İ.F.V Publications, Istanbul. 
Soyal M, Çelik N, Pekel A, 2017. An investigation of the relationship between the reaction times and the state and trait anxiety levels of the athletes. European Journal of Physical Education and Sport Science, 3(12), 523-533.

Şahin E, Özdal M, 2020. Effect of Core Exercises on Balance and Vertical Jump of 12-14 Aged Female Volleyball Players. European Journal of Physical Education and Sport Science, 6(4), 47-55.

Şimşek KY, 2005. Study on the evaluation of the parents' opinions as to the sport orientation of children. Master's Thesis, University of Anadolu.

Ural A, Kılıç İ, 2005. Scientific research process and data analysis with SPSS, Deta Publishing, Ankara.

Wathins D, Regmi M, 1990. Participation in sport: A Nepalese investigation Perceptual and Motor Skills, 69(2), 657-658.

Voigt D, 1988. Sports Sociology. (Translation: Ayşe Atalay). Remzi Bookstore, Istanbul. 
Fatma Beyza Bilgiç, Murat Bilgiç, Hüseyin Öztürk

Creative Commons licensing terms

Authors will retain the copyright of their published articles agreeing that a Creative Commons Attribution 4.0 International License (CC BY 4.0) terms will be applied to their work. Under the terms of this license, no permission is required from the author(s) or publisher for members of the community to copy, distribute, transmit or adapt the article content, providing a proper, prominent and unambiguous attribution to the authors in a manner that makes clear that the materials are being reused under permission of a Creative Commons License. Views, opinions and conclusions expressed in this research article are views, opinions and conclusions of the author(s). Open Access Publishing Group and European Journal of Physical Education and Sport Science shall not be responsible or answerable for any loss, damage or liability caused in relation to/arising out of conflict of interests, copyright violations and inappropriate or inaccurate use of any kind content related or integrated on the research work. All the published works are meeting the Open Access Publishing requirements and can be freely accessed, shared, modified, distributed and used in educational, commercial and non-commercial purposes under a Creative Commons attribution 4.0 International License (CC BY 4.0). 